\title{
Erratum to: Associations of multisite pain with healthcare utilization, sickness absence and restrictions at work
}

Rita de Cássia Pereira Fernandes ${ }^{1,2} \cdot$ Alex Burdorf $^{2}$

Published online: 28 June 2016

(C) Springer-Verlag Berlin Heidelberg 2016

\section{Erratum to: Int Arch Occup Environ Health DOI 10.1007/s00420-016-1141-7}

In the original publication, the first author's name was incorrectly published as Rita Cássia Pereira de Fernandes. The correct name should read as "Rita de Cássia Pereira Fernandes".

The online version of the original article can be found under doi:10.1007/s00420-016-1141-7.

$\triangle$ Alex Burdorf

a.burdorf@erasmusmc.nl

http://www.erasmusmc.nl

http://www.erasmusmc.nl/mgz

1 Department of Social and Preventive Medicine, School of Medicine, FMB, Federal University of Bahia, Largo do Terreiro de Jesus, s/n. Centro Histórico, Salvador, Bahia 40026-010, Brazil

2 Department of Public Health, Erasmus MC, University Medical Center Rotterdam, P.O. Box 2040, 3000

CA Rotterdam, The Netherlands 